\title{
IMPROVING LEARNERS' ENGLISH PROFICIENCY THROUGH LEARNING STRATEGY INSTRUCTION
}

\author{
Suswati Hendriani \\ Program Studi Tadris Bahasa Inggris Jurusan Tarbiyah STAIN Batusangkar \\ Korespondensi: Jl. Komplek Arai pinang 1 Blok. I No. 6 Kuburajo Lima Kaum Batusangkar. \\ e-mail: suswati_amor@gmail.com
}

\begin{abstract}
English mastery has become more important in this era. English teachers, therefore, are expected to help students to get much success in their language learning by making them aware of the importance of their contribution in learning the language and, then, teaching them language learning strategies. The effectiveness of the instruction is really determined by both the teachers and the language learners. To be more effective, the instruction should be highly practical and useful for students
\end{abstract}

Key words: improving, foreign language learner, english proficiency, learning strategy, instruction

\section{INTRODUCTION}

I $\mathrm{n}$ this era of globalization and information, English language mastery as an international language is urgent. Inability to master the language will cause someone, including a student, miss much important information. It is undeniable that such information is available in English. Therefore, to gain as much information as possible, he or she must master the language well. In other words, he or she has to master the four language skills, i.e. listening, speaking, reading, and writing well so that he or she will be able to communicate either orally or in written.

Oral communication requires that someone master listening skills and speaking skills. Through listening skills much information from electronic media, like television and radio may be absorbed so that it will open one's horizon and improve his or her insight about the world which seems to get smaller and smaller. Through good speaking skills, he or she will be able to express his or her thoughts, feelings, and ideas to others in that language. On the other hand, written communication requires the he or she have ability to understand information from internet or printed media like English magazines and newspapers through his or her reading skills. Whereas, if he or she would like to communicate his or her thoughts, ideas, and feelings in written form, he or she also needs too master writing skills well. Through the writing skills, one can influence others through his or her written ideas and written thoughts.

Considering the importance of English language mastery, English teachers are expected to provide their students with the language skills mentioned previously in order that they get success in their English language learning since teachers is an external factor which can help students to get much 
success in their language learning. Rubin and Thompson (1982: 3) state:

You, the language learner, are the most important factor in the language learning process. Success or failure will, in the end, be determined by what yourself contribute. Many learners tend to blame teachers, circumstances, and teaching materials for their lack of success, when the most important reasons for their success or failure can ultimately be found in themselves.

Based on the idea above, it can be concluded that the students' success will depend on how much they contribute in their language learning. How can they contribute much? What can the teachers do to help them contribute much to get their success? There are many ways that the teacher can use such as using facilitating media, varying his teaching techniques, motivating the students to learn English better, creating conducive classroom atmosphere and teaching learning strategies to the students many others.

One of the ways that the teachers can use is teaching or training the students learning strategies explicitly. Through the learning strategy instruction or training, they are expected to be more involved and more contributive to their English language learning which, in turn, helps them get success. Oxford (1990: 22) concludes that language learning strategies are important to get success in language learning. In addition, Brown (2002: vii) states that successful language learners are those who understand their own abilities and capacities well and who autonomously engaged in systematic efforts within and beyond the classroom to reach self-determined goals of acquisition. Moreover, Brown (2002: Xiii) states that successful students spend a lot of time doing the following things: setting goals on their own, practicing with other people outside of class, analyzing their own mistakes in conversations, and using many different strategies for learning.

Based on previous descriptions, this paper, therefore, aims at describing the technique to improve learners' English proficiency through learning strategy instruction

\section{WHAT IS LEARNING STRATEGY?}

Learning strategy has been defined by experts. However, in this article, the writer will give definition based on three experts. Oxford (1990: 1) states:

Learning strategies are steps taken by students to enhance their own learning. Strategies are especially important for language learning because they are tools for active, self-directed involvement, which is essential for developing communicative competence. Appropriate language learning strategies result in proficiency and greater self-confidence.

While Chammot.et.al., (1999: 5) points out "Learning strategies are an integral part of language programs, providing students with the tools for a lifetime of learning"

From the ideas above, it can be concluded that learning strategy is the steps or techniques applied by foreign language learners so that they can develop and master the foreign language well

\section{TYPES OF LEARNING STRATEGY}

A good language learner according to Harmer (2004) has five characteristics. They are: "A willingness to listen, a willingness to experiment, a willingness to ask questions, a willingness to think about how to learn, and a willingness to accept correction".

Rubin dan Thompson (1982) implicitly state that there are 14 types of 
learning strategy that can be used by language learners. They are: 1). Find your own way, 2) Organize, 3) Be creative, 4) Make your own opportunities, 5) Learn to live with uncertainty, 6) Use mnemonics, 7) Make your errors work, 8) Use your linguistic knowledge, 9) Let context help you, 10) Learn to make intelligent guesses, 11) Learn some lines as wholes, 12) Learn formalized routines, 13) Learn production techniques, dan 14) Use different styles of speech

Oxford (1990: 14-16) implicitly states that there are two big categories of learning strategies. They are direct strategies and indirect strategies. Direct strategies includes memory strategies, cognitive strategies, and compensation strategies. Indirect strategies, on the other hand includes: metacognitive strategies, affective strategies, and social strategies.

Memory strategies inldudes creating mental linkages, applying images and sounds, reviewing well, and employing action. Creating mental linkages can be applied through grouping, associating/elaborating, and placig a new word into a context. Applying images and sounds can be applied through for techniques, i.e., using imagery, semantic mapping, using keywords, and representing sounds in memory. Reviewing well can be applied through structured reviewing. While employing action can be applied by using physical response or sensation and using mechanical techniques.

Cognitive strategies are applied through practicing, receiving and sending messages, analyzing and reasoning, and creating for structure for input and output. Practicing will be done through repeating, formally practicing with sounds and writing systems, recognizing and using formulas and patterns, recombining dan practicing naturalistically. Receiving and sending messages will be applied through getting the idea quickly and using resources for receiving and sending messages. Analyzing and reasoning can be done through reasoning deductively, analyzing expressions, analyzing contrastively (across languages), translating and transferring. Creating structure for input and output will be applied through taking notes, summarizing, and highlighting.

Compensation strategies include guessing intelligently, dan overcoming limitations in speaking and writing. Guessing intelligently will be applied diterapkan dengan cara: using linguistic clues dan using other clues. Sedangkan overcoming limitations in speaking and writing dapat ditempuh melalui delapan cara, yaitu: switching to the mother tongue, getting help, using mime or gesture, avoiding communication partially or totally, selecting the topic, adjusting or approximating the message, dan using a circumlocution or synonyms.

Indirect strategies are grouped into three main categories. They are metacognitive strategies, affective strategies, and social strategies. Metacognitive strategies can be implemented through: centering your learning, arranging and planning your learning, and evaluating your learning. Affective strategies involve lowering your anxiety, encouraging yourself, and taking your emotional temperature. While, social strategies include asking questions, cooperating with others, and emphatizing with others. .

O'Malley et al. (1985b: 582-584) group the strategy into three categories as they are shown in the following table: 


\begin{tabular}{ll}
\hline \multicolumn{1}{c}{ LEARNING STRTEGY } & \multicolumn{1}{c}{ DESCRIPTION } \\
\hline Metakognitive Strategies & $\begin{array}{l}\text { Making general but comprehensive } \\
\text { preview of the Organizing concept or } \\
\text { principle in an anticipated learning } \\
\text { activity }\end{array}$ \\
\hline Directed Attention & $\begin{array}{l}\text { Deciding in advance to attend in general } \\
\text { to a learning task and to ignore irrelevant } \\
\text { distractors }\end{array}$ \\
\hline Selective Attention & $\begin{array}{l}\text { Deciding in advance to attend to specific } \\
\text { aspects of language input or situational } \\
\text { details that will cue the }\end{array}$ \\
Retention of language input \\
\hline Self-Management & $\begin{array}{l}\text { Understanding the conditions that help } \\
\text { one learn and arranging for the presence } \\
\text { of those conditions }\end{array}$ \\
\hline Functional Planning & $\begin{array}{l}\text { Planning for and rehearsing linguistic } \\
\text { components necessary to carry out an } \\
\text { upcoming language task }\end{array}$ \\
\hline Self-Monitoring & $\begin{array}{l}\text { Correcting one's speech for accuracy in } \\
\text { pronunciation, grammar, vocabulary, or } \\
\text { for appropriateness related to the setting } \\
\text { or to the people who are present }\end{array}$ \\
\hline Consciously deciding to postpone \\
speaking in order to learn initially through \\
listening comprehension
\end{tabular}

\section{Cognitive Strategies}

\begin{tabular}{ll}
\hline Repetition & $\begin{array}{l}\text { Imitating a language model, including } \\
\text { overt practice and silent rehearsal }\end{array}$ \\
\hline Resourcing & Using target language reference materials \\
\hline Translation & $\begin{array}{l}\text { Using the first language as a base for } \\
\text { understanding and/or producing the } \\
\text { second language }\end{array}$ \\
\hline Grouping & $\begin{array}{l}\text { Reordering or reclassifying, and perhaps } \\
\text { labeling, the material to be learned based } \\
\text { on common attributes }\end{array}$ \\
\hline Note Taking & $\begin{array}{l}\text { Writing down the main idea, important } \\
\text { points, outline, or summary of } \\
\text { information presented orally or in writing }\end{array}$ \\
\hline Deduction & $\begin{array}{l}\text { Consciously applying rules to produce or } \\
\text { understand the second language }\end{array}$ \\
\hline Recombination & Constructing a meaningful sentence or \\
\hline
\end{tabular}




\begin{tabular}{|c|c|}
\hline & $\begin{array}{l}\text { larger language sequence by combining } \\
\text { known elements in a new way }\end{array}$ \\
\hline Imagery & $\begin{array}{l}\text { Relating new information to visual } \\
\text { concepts in memory via familiar, easily } \\
\text { retrievable visualizations, phrases, or } \\
\text { locations }\end{array}$ \\
\hline Auditory Representation & $\begin{array}{l}\text { Retention of the sound or a similar sound } \\
\text { for a word, phrase, or longer language } \\
\text { sequence }\end{array}$ \\
\hline Ketword & $\begin{array}{l}\text { Remembering a new word in the second } \\
\text { language by (1) identifying a familiar } \\
\text { word in the first language that sounds like } \\
\text { or otherwise resembles the new word and } \\
\text { (2) generating easily recalled images of } \\
\text { some relationship between the new word } \\
\text { and the familiar word }\end{array}$ \\
\hline Contextualization & $\begin{array}{l}\text { Placing a word or phrase in a meaningful } \\
\text { language sequence }\end{array}$ \\
\hline Elaboration & $\begin{array}{l}\text { Relating new information to other } \\
\text { concepts in memory }\end{array}$ \\
\hline Transfer & $\begin{array}{l}\text { Using previously acquired linguistic } \\
\text { and/or conceptual knowledge to facilitate } \\
\text { a new language learning task }\end{array}$ \\
\hline Inferencing & $\begin{array}{l}\text { Using available information to guess } \\
\text { meanings of new items, predict outcomes, } \\
\text { or fill in missing information }\end{array}$ \\
\hline
\end{tabular}

\section{Socioaffective Strategies}

\begin{tabular}{ll}
\hline Cooperation & $\begin{array}{l}\text { Working with one or more peers to obtain } \\
\text { feedback, pool information, or model a } \\
\text { language activity }\end{array}$ \\
\hline Question for Clarification & $\begin{array}{l}\text { Asking a teacher or other native speaker } \\
\text { for repetition, paraphrasing, explanation, } \\
\text { and/or example }\end{array}$ \\
\hline
\end{tabular}

Nunan in Richards and Renandya (2002: 135) state that there are four learner strategies in learning in classroom. They are as follow:

1. Stimulating a focus on the learning process

2. Focusing on the context and environment of the learning process

3. Dealing with the macro-skills

4. Strategies for dealing with pronunciation, vocabulary, grammar, and discourse.
Discussing about learning strategy, Brown (2002) states that to be successful, there are twelve strategies that can be applied through questioning these 12 points. They are as follow: 1) What kind of learner are you? 2) Discovering your listening styles. Left 3) Brain and Right Brain. 4) Motivating Yourself and Setting Goals, 5) Developing self-Confidence and Lowering Anxiety, 6) Learning to Take Risks, 7) What's Your Language-Learning IQ?, 8) The influence of Your Native Language, 9) Learning a 
Second Culture, 10) Using Individual Learning Strategies, 11) Using Group Strategies, and 12) Strategies for Taking Tests

Based on the quotations cited, it can be concluded that there are several types of learning strategy that can be implemented by foreign language learners in their language learning.

\section{HOW TO IMPROVE ENGLISH PROFICIENCY THROUGH LEARNING STRATEGY INSTRUCTION?}

Before discussing on how to improve English Proficiency, the citation of Oxford's (1990: 1) will be important. She states "Appropriate language learning strategies result in improved proficiency and greater self confidence"

Related to that idea, J. Michael O'Malley in Wenden and Rubin (1987: 133) mentions " research and theory in second language learning strongly suggest that good language learners use a variety of strategies to assist them in gaining command over new language skills". In line with him, Brown (1994: 190) states that successful language learners have achieved their goals through conscious, systematic application of a battery of strategies

Based on the idea above, it can be concluded that foreign language learners' proficiency will be improved if the can apply appropriate learning strategies. To actualize the idea is not easy. Therefore, they need to be instructed learning strategies because learning strategies are the important tools in their foreign language learning. The language learning strategies used by a language learner will really influence his or her language proficiency.

Considering the importance of learning strategies for students, foreign language teachers need to train their students in using those strategies since Wragg in McInerney and McInerney (1998: 800 states "successful teachers had higher expectations for students and saw themselves primarily as instructors whose task it was to help them learn". This is supported by Oxford (1990: 201) who states:

Learners need to learn how to learn. And teachers need to learn how to facilitate the process. Although learning is certainly part of the human condition, conscious skill in selfdirected learning and in strategy use must be sharpened through training. Strategy training is especially necessary in the area of second and foreign languages. Language learning ...Strategy training should not be abstract and theoretical but should be highly practical and useful for students.

Before discussing about how to conduct the learning strategy instruction effectively, it is necessary to pay attention to the idea of Chamot et.al., (1999: 35-36) who remind to consider several factors related with the instructor and the learners, and the instruction for effective learning strategy instruction, below:

Both individual and instructional factors can impact the effectiveness of learning strategies instruction. These factors include the beliefs of both students and teachers regarding learning, the social climate of the learning setting, and general approaches to instruction used in the classroom.

If those factors can be controlled well, the next step is instructing the strategies. What steps to be followed in order to optimize the use of the learning strategies? Related to this, Herrel (1988: xiv) suggests that:

1. Teachers should provide instruction in a way that ensures that students are given comprehensible 
input (language they can understand).

2. Teachers should provide opportunities to increase verbal interaction in classroom activities.

3. Teachers should provide instruction that contextualize language as much as possible.

4. Teachers should use teaching strategies and grouping techniques that reduce the anxiety of the students as much as possible/

5. Teachers should provide activities in the classroom that offer opportunities for active involvement of the students.

Moreover, Herrell (1988: 115) describes the steps in teaching learning strategies as follow:

1. Select the strategy to be taught by thinking about the curriculum to be studied and the demands it will make on the learner. Plan to teach only a few strategies well before introducing new ones.

2. Develop students' self-awareness by having them reflect on how they approach a learning task. Remind them of the cooperative learning activities they have been involved with and what they have learned about their approaches to learning during the debriefing sessions.

3. Model the strategy you are teaching. Call the strategy by its name each time you model it. Explain how the strategy works to support the students' learning. Give examples of instances in which the strategy will be helpful.

4. Provide an opportunity for the students to practice using the strategy.

5. Hold an evaluation discussion. Ask the students to demonstrate how they used the strategy and what was difficult for them. Provide a self-evaluation tool, or scoring rubric, for them to use in evaluating their strategy use.

6. Have the students make strategy posters to display in the classroom which explain the steps in the strategy use. Refer to those posters frequently when making assignments. Help the students to see that they have choices in strategies to use and that strategies can be used in many different contexts and learning tasks.

While, Brown (2000: 131) states that there are several different models of Strategy-Based Instruction or learning strategy training being practiced in language classes around the world.

1. As part of a standard communicative methodology, teachers help students to become aware of their own style preferences and the strategies that are derived from those styles (Thompson \& Rubin 1996, Oxford 1990a). (See also the "In the Classroom" vignette at the end of this chapter for some details.) Through checklists, tests, and interviews, teacher can become aware of students' tendencies and then offer advice on beneficial in-class and extra-class strategies.

2. Teachers can embed strategy awareness and practice into their pedagogy (Rubin \& Thompson 1994; Brown 1989, 1990; Ellis \& Sinclair 1989). As they utilize such techniques as communicative games, rapid reading, fluency exercises, and error analysis, teachers can help students both consciously and subconsciously to practice successful strategies.

3. Certain compensatory techniques are sometimes practiced to help students overcome certain weaknesses. Omaggio (1981) provided diagnostic instruments and procedures for determining students' 
preferences, then outlined exercises that help students to overcome certain blocks or to develop successful strategies here they are weak.

4. Finally, textbooks (Brown 1998, Chammot, O'Malley \& Kupper 1992) include strategy instruction as part of a content-centered approach.

In addition, Brown (1994: 200) also states that there are some ways of how to teach strategies in the classroom. They are:

1.h strategies through interactive techniques

2. Use compensatory technique

3. Administer a strategy inventory

\section{BIBLIOGRAPHY}

Brown, H. Douglas. 1994. Teaching by Principles: An Interactive Approach to Language Pedagogy. New Jersey: Prentice hall Regents.

- 2000. Principles of Language Learning and Teaching (fourth edition). New York: Addison Wesley Longman, Inc.

. 2002. Strategies for Success: A Practical Guide to Learning English. New York: Addison Wesley Longman.

. 2004. Language Assessment: Principles and Classroom Practices. New York: Pearson Education.

Chammot Anna Uhl.et.al.,. 1999. The Learning Strategies Handbook. New York: Addison Wesley Longman.

Herrell, Rienne. L. 1988. Fifty Strategies for Teaching English Language Learners. Ohio: Prentice Hall.
4. Impromptu teacher-initiated advice.

\section{CONCLUSION}

Based on previous theories, it is clear that learning strategies are very important for foreign language learners. There are many types of language learning strategies that can be applied by them. Yet, to apply those strategies they must be aware of the strategies. Therefore, foreign language teachers need to expose the learning strategies and train their students in using the learning strategies, By doing so, it is expected that they will be more successful in their language learning.

Larsen-Freeman, Diane, and Long, Michael. H. 1991. An Introduction to Second Language acquisition Research. London: Longman.

McInerney, Dennis. M and McInerney, Valentina. 1998. Educational Psychology: Constructing Learning (Second Edition). Sydney: Prentice Hall of Australia Pty Ltd

O'Malley, et.al., 1985b. Learning Strategy Applications with Students of English as a Second Language. Tesol Quarterly 19. 557-584

Oxford, Rebecca L.1990. Language Learning Strategies: What Every Teacher Should Know. New York: Newbury House publishers.

Rubin, Joan and Thompson, Irene. 1982. How to be More Successful Language Learner. Boston: Heinle $\&$ Heinle Publishers.

Wenden, Anita and Joan Rubin. 1987. Learner Strategies in Language Learning. New Jersey: PrenticeHall International (UK). 

